\title{
Puccinia scillae (Uredinales), a new species for Poland
}

\author{
MAłGORZATA RUSZKIEWICZ-MICHALSKA and MAREK MICHALSKI
}

Department of Algology and Mycology, University of Lodz.

Banacha 12/16, PL-90-237 Eódź, mrusz@biol.uni.lodz.pl

Ruszkiewicz-Michalska M., Michalski M.: Puccinia scillae (Uredinales), a new specics for Poland. Acta Mycol. 40 (1): 63-70, 2005.

The paper presents a rust species new for Poland, that affects the ornamental plant Scilla siberica Haw. The distribution of the fungus and its host plants, both introduced and native in Europe, have been investigated. The data from neighbouring countries indicate that the parasite has been probably overlooked in Poland till now. There is a possibility, however, that the species is currently spreading in central and north-eastern Europe.

Key words: parasitic fungi, rust fungus, Scilla siberica, distribution, Central Poland

\section{INTRODUCTION}

Observations of the occurrence of phytopathogenic fungal species new for the Polish mycobiota or a new host of an already known pathogen have not been rare events in the last decade. Each year brings new records of such a kind. This concerns both groups so well documented in Poland as Peronosporales, Erysiphales, Uredinales and Ustilaginales (Mułenko and Matejko Gosztyła 1997; Madej, Błaszkowski and Tadych 2001; Piątek 2003, 2004) as well as relatively less known sac fungi (Ascomycotina) and their anamorphs (Ruszkiewicz 2000; Wołczańska and Oklejewicz 2001; Chlebicki 2002; RuszkiewiczMichalska and Mułenko 2003; Adamska 2004). It is difficult to decide which of the new species were not recorded before just because of their ephemeral occurrence, an insufficient knowledge of a taxonomic group, and which taxa are true fast spreading invasive organisms. Data coming from neighbouring countries and several years of recordings in Poland, which allow to trace spreading of a species are very valuable. Best documented is the history of migration of pathogens of crop and ornamental plants, e.g. Phytophthora infestans (Mont.) de Bary, Uncinula necator (Schw.) Burrill, Puccinia antirrhini Diet. et Holw. (Eawrynowicz and Sa ta ta 1992). Invasive taxa spreading in Poland are, e.g. Microsphaera alphitoides Griff. et Maubl. (Mułenko et al. 2005) and recently Erysiphe fiexuosa (Peck) U. Braun [= Uncinula flexuosa Peck] (Piątek 2002; Wołczańska and Mułenko 2002) 
whose migration has been recorded in other European countries, too (Ale-Ag ha ct al. 2000; Zimmermannová-Pastirčá ková et al. 2002). Spreading of several other species of unclear status has been observed in Central-Eastern Europe: e.g. powdery mildews Erysiphe howeana U. Braun and Sphaerotheca spiraeae Sawada (Piątek 2000, 2004; Wołczańska and Mułenko 2002) and rust Melampsoriđium hiratsukanum S. Ito on Alnus spp. (Põldma a 1997; Wołczańska 1999; Piątek, Ronikier and Miśkiewicz 2001).

\section{FUNGUS DISTRIBUTION AND HOST RANGE}

According to Gäuma n (1959) Puccinia scillae Linhart [ = P litiaceanum Duby ssp. rossiana Sacc,; P. rossiana (Sacc.) Lagerh.] is a species of Micropuccinia group occurring all over Europe. Müller (1977) presented the first description of spermogonia of that species and suggested to move it to Hypopuccinia. The presence of $P$. scillae has been confirmed in southern and southwestern Europe: in Austria (Scheuer and Poelt 1997; Scheuer 1998, 2000), Germany (Müller 1977; Brandenburger 1994; Krieglsteiner 1999), Greece (Panditou 1973), Hungary (Sydow P. and Sydow H. 1904; Bánhegyi et al. 1985), Italy (Trotter 1908), Romania (Săvulescu 1953), Switzerland (Fischer 1904), on the territory of the former USSR (Tranzschel 1939), and recently also in Estonia (Põ Id ma a 1999). In these territories it infects two from 15 European representatives of the genus Scilla (T ut in et al. 1996), namely S. bifolia L. s.l. (incl. S. vindobonensis Speta) and $S$. siberica Haw. [ $=S$. sibirica Andrz.; $S$. cemua Red.]. This rust specics, however, has not been found in most of the Central and Northern European countries: Poland (Majewski 1979; Majewski and Ruszkiewicz-Michalska 2005 unpubl,), Lithuania (Minkevićius and Ignavičiz̄t ć 1993), Denmark (Latin Danish Taxon Database) and in Finland, Norway and Sweden (Farr et al. [n.d.]).

The data from the beginning of the $20^{\text {th }}$ century indicate that $P$ scillae was not found in the Czech Republic, either (Bubák 1906). According to Mülle r (1977) the first records of $P$. scillae in this area come from 1939 (unpublished) and from 1960. In his work Mülle r (l.c.) presented an analysis of the distribution of this rust species in Europe against the range of its two hosts: Scilla bifolia and S. siberica. He found $P$. scillae to be an Eastern-Central European species with a centre of occurrence in Ukraine. Only in this territory $P$. scillae has been found on both host species (Rouppert and Wróblewski 1910; Zweigbaumówna 1918; Wróblewski 1922; Wroblewski and Sicmaszko 1933; Minter and Dudka 1996).

\section{MATERIAL AND METHODS}

Puccinia scillae was found in spring of 2004 and 2005 in the centre of Lódź city (Poland). It infected specimens of Scilla siberica cultivated as ornamental plant causing hypertrophic deformation of their leaves (Fig. 1).

SPECimens examined. On Scilla siberica: Central Poland, Lódź, Bp. M. Klepacz park $\left(51.45^{\prime} \mathrm{N} / 19.28^{\prime} \mathrm{E}\right)$, in the lawn, abundant, 10 May 2004, (teliospores), LOD 458; same host and locality, 8 April 2005, (spermogonia), LOD 459; same host and locality, 12 April 2005, (teliospores), LOD 506; leg. M. Michalski. 


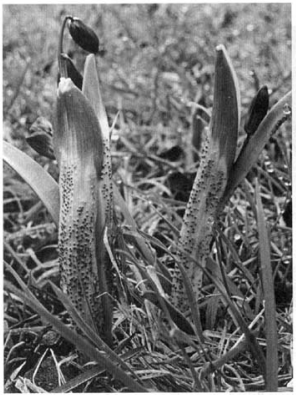

Fig. 1. The infected plants of Scilla siberica Haw.

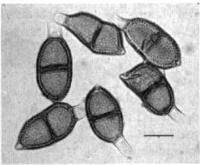

Fig. 2. Teliospores of $P$ scillae (bar $=20 \mu \mathrm{m})$.

The morphological features and dimensions of teliospores (Fig. 2) correspond to the description given by Majewski (1979) and Brandenburger (1985).

$S$ siberica, originating from Western Asia, has been cultivated in Poland and sometimes it grows naturalized (M ir ek et al. 2002; Rutkowski 2004). The other of the squills species found in Poland, the native $S$. bifolia (incl. ssp. subtriphylla $[=S$. kladnii Schur $]$ ), grows in the southern, mountainous part of Poland and it has a number of anthropogenic sites in Greater Poland and Western Pomerania (Zając A. and Zając M. eds 2001; Piękos-Mirkowa and Mirek 2003).

\section{DISCUSSION}

No representatives of Uredinales have been recorded on the genus Scilla until now in Poland (Majewski 1977, 1979; Majewski and Ruszkiewicz-Michalska 2005 unpubl.). In other European countries species of the genus Scilla L. and related genera, e.g. Hyacinthoides Med., Chionodoxa Boiss. and Muscari Mill., have been parasitiscd by $P$ scillae and two other widespread rusts: heteroaècious $P$ uccinia scillae-rubrae P. Cruchet [P. piperi Ricker ssp. scillae-rubrae (P. Cruchet) Cummins; Aecidium scillae Fuck) (Panditou 1973; Denchev 1995; Minter and Dudka 1996; Triebel 1995-2004; Minter et al. 2005) and Uromyces muscari (Duby) Graves [U. scillarum (Grev, ex Berk.) Wint.] (Pa nditou 1973; B r anden burger 1994; Reid 1985; Denchev 1995; Minter et al. 2005; Farr et al. [n.d.]). The last species has been reported in Poland on Muscari spp. (Majewski 1997) from Lower Silesia (Fig. 3).

Wróblewski (1916) described Caeoma scillae - an aecial stage of Melampsora sp. on Scilla bifolia coming from the territory of the Ukraine (Wierbiąż Niżny near Kolomya). The telial host of this parasite has not been known so far (Majewski 


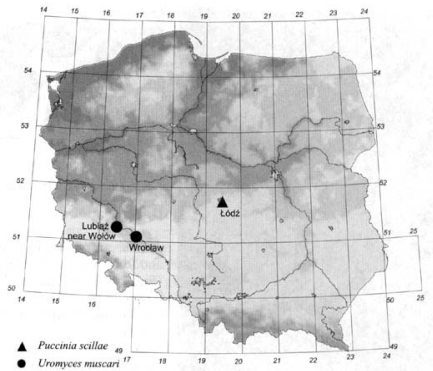

Fig. 3. Distribution of localities of the fungi in Poland.

1977). This species was then recorded in other European countries (Majewski 1977; Brandenburger 1994).

P. scillae-rubrae has been recorded exclusively on $S$. bifolia so far whereas the spectrum of hosts of $U$, muscari is quite wide and includes several related taxa: Scilla bithynica Boiss., S. peruviana L., S. puschkinioides Regel (endemic to Central Asia), $S$. verna Huds., Hyacinthoides hispanica (Mill.) Rothm. [= Scilla campanulata Aiton ], H. non-scripta (L.) Chouard ex Rothm. [= Hyacinthus non-scriptus L., Scilla non-scripta (L.) Hoffmanns. et Link], Hyacinthus orientalis L., Muscari botryoides (L.) Mill. [= Hyacinthus botryoides L.], M. comosum (L) Mill. [= Hyacinthus comosus L.], M. neglectum Guss. ex Ten. [= Hyacinthus racemosus L.], M. teruiftonum Tausch., and a few species of Bellevalia, Chionodoxa, Leopoldia and Ormithogalum. It corresponds to results of the research concerning taxonomical relations inside the genus Scilla and relationships between this taxon and other representatives of the family Hyacinthaceae (Fischer, Fe reszty and Kiss 1985; Speta 1998; Wetschnig and Pfosser 2003). Genus Scilla is most probably of polyphyletic origin and it is closely related to Hyacinthoides Med. [= Endymion Dumort.], Hyacinthus L., Chionodoxa Boiss., Ornithogalum L. and Muscart Miller. Especially members of Scilla and Hyacinthus are extensively intermixed with each other and the only truc Scilla species consisting of a monophyletic clade are those in the Mediterranean region (Pfosser and Speta 1999).

Geophytic occurrence of Scilla species and a poor mycological knowledge of its native communities (Dentario glandulosae-Fagetum association) and anthropo- 
genic habitats (Lawrynowicz, Bujakiewicz and Mułenko 2004) may be a cause for the lack of earlier reports about the occurrence of $P$. scillae in Poland. That species was not reported from other countries, where Scilla species were cultivated and never wild-growing, e.g. in France, Scandinavia (Farr et al. [n.d.]), in Great Britain (The checklist of fungi of the British Isles 2005), New Zealand (A nony mous 2001-2005) and in United States of America (Farr et al. 1989; Fa r r et al. [n.d.]). The confirmation of phytopathologists' interest in the genus Scilla in these countries is reflected in records of other fungi parasitising it, e.g. Fusicladium scillae (Deighton) U. Braun (A n o ny mous 2001-2005), Pythium sp., Septoria scillae West. ex Kickx f., Urocystis scillae (Cif.) Zundel (Fa r r et al. [n.d.]) and Ustilago vaillantii L. R. Tul. et C. Tul. (V á n ky 1994).

\section{CONCLUSIONS}

The occurence of Puccinia scillae has probably been overlooked in Poland until now. Possibly it results from the insufficient level of research focused on anthropogenic habitats. The presented data from neighbouring countries, especially the recent records of that species from Estonia, suggest that Puccinia scillae may currently spread in the Central-Eastern part of the continent. This kind of conclusion should however be confirmed by further records from other countries, where it has not been observed yet. The expansion of this species may be associated with a worse condition of its hosts growing beyond their natural habitats in locations exposed to greater anthropopressure.

Aknowledgements: We are very indebted to Prof. Tomasz Majewski (Department of Plant Pathology. Warsaw Agricultural University) for providing important literature and his comments on the manuscript We are grateful to Dr Stefan Helfer (Royal Botanical Garden, Edinburgh) and Dr Kadri Poldmaa (Department of Mycology, Estonian Agricultural University) for their kind help in checking the data on distribution of the fungus, and to Dr Joanna Zelazna-Wieczorek (Department of Algology and Mycology. University of Lodź) for offering her facilities for microphotographic documentation. We would like to express our thanks to Dr Michat Grabowski (Department of Polar Biology and Oceanology, University of Lódź) who has helped us as linguistic adviser.

The study was partially supported by the Ministry of Scientific Research and Information Technology (MNII) (grant no 2 P04C 05227 ).

\section{REFERENCES}

Adamska I. 2004. Schizothyrioma ptarmicae (Helotiales, Ascomycota), a rare European fungus newly found in Poland. Acta Soc. Bot. Poloniac 73 (1): $57-59$.

Ale-Agha N., Brau n U., Feige B., J age H. 2000. A new mildew diseae on Aesculus spp. introduced in Europe. Cryptogamie Mycol. 21 (2): 89-92.

An onym ous. 2001-2005. NZFUNGI Database of New Zealend Fungi. Landcare Rescarch, New Zealand. Available http://nzfungi.landcare research,co.nz/ (Accessed 12 October 2005).

Bánhegyi J., Tòth S., Ubrizsy G, Voros J. 1985. Magyarország mikroszkopikus gombáinak határozòkünyve, 2. Eumycola. Akadémiai Kiadó, Budapest.

Brandenburger W. 1985. Parasitische Pilze an Gefaßpflanzen in Europa. G. Fischer Verlag, Stuttgart-New Yotk.

Brandenburger W. 1994. Distribution of rust fungi (Uredinales) in the western part of the Federal Republic of Germany. A survey based on data from literature. Regensb. Mykol. Schr. 3: 1-181.

Bubák F. 1905. Houby Ceské. 1. Rezy (Uredinales). Archiv. pro přirodovědecke prozkoumáni Céch. Svazck XIII, cis. 5, Praha: 1-226. 
Chlebicki A. 2002. Biogeographical relationships between fungi and selected glacial relic plants. The use of host-fungus data as an aid to plant geography on the basis of material from Europe, Green. land and Northern Asia. Monogr. Bot. 90: 1-230.

Denchev C.M. 1995. Bulgarian Uredinales. Mycotaron 55: 405-465.

Farr D.F. Bills G.F., Chamuris G.P., Rossman A.Y. 1989. Fungi on plants and plant products in the United States. APS Press, St. Paul, Minnesota.

Farr D.F., Rossman A.Y., Palm M.E., McCray E.B. [n.d.], Fungal Databases, Systematic Botany \& Mycology Laboratory, ARS, USDA. Retrieved October 12, 2005, from http:/int,ars-grin.gow/fungaldatabases/.

Fischer E. 1904. Die Uredincen der Schweiz. (In:) Beiträge zur Kryptogamenflora der Sehweiz. Band II, heft 2. - Bem.

Fischer J., Fereszty Z., Kiss N. 1985. Character ranking for the Scilla bifolia aggregate in Hungary by the application of SCAGA, a new technique of categorization. Acta Bot. Hung. 31 (1/4): 205 . 224.

Gä umann E. 1959. Die Rostpilze Mitteleuropas, mit besonderer Berücksichtigung der Schweiz. (In:) Beitrảge zur Kryptogamenflora der Schweic. Band XIL. Bern.

Krieglsteiner L. 1999. Fungi of Lower Franconia and their occurrence in different types of vegetation. Regensb, Mykol. Schr. 9 (2): 1-464.

Latin-Danish Taxon Database. Danish Mycological Society [http://www.mycosoc.dk].

Ławrynowicz M., Bujakiewiez A., Mulenko W. 2004. Mycocoenological studies in Poland. 1952. .2002. Monogr. Bot. 93: 1-102.

Eawrynowicz M, Salata B. 1992. Some phytoparasitic fungi introduced in Poland after discovering of America. (In:) M. Lawrynowicz, A.U. Warcholińska (eds). Rosliny pochodzenia amery. kańskiego zadomowione w Polsce: 9-16. Lódzkic Towarzystwo Naukowe, Lódé.

Madej T., B laszkowski J., T adych M. 2001. Ustilago trichophora (H. F. Link) F. Kömicke, a fungus newly found in Poland. Acta Soc. Bot. Poloniae $70(1): 43-46$.

Majewski T 1977. Flora Polska. Grzyby (Mycota) 9; Basidiomycetes, Uredinales. I. PWN, Warszawa. Kraków.

Majewski T. 1979. Flora Polska. Grzyby (Mycota) 11: Basidionycetes, Uredinales. II. PWN, WarszawaKraków.

Majewski T., Ruszkiewiez-Michalska M. 2005 (unpbl.). Uredinales. (In:) W. Mułenko, T. Majewski (eds). The Polish Microfungi. A checklist. Biodiversity of Poland 9. W. Szafer Institute of Botany PAS.

Minkevičius A., Ignaviči ü tè M. 1993. Mycota Lithuaniae. V. Uredirales 2. Genus Puccina. Instit. Bot. Lithuaniae, Univ, Vilnensis, Vilnius.

Minter D.W. Du dka I.O. 1996. Fungi of Ukraine. A preliminary checklist. CAB International.

Minter D.W. Hayova V.P., Thomas A.H., Tykhonenko Yu. Ya. 2005. Electronic Distribution Maps of Ukrainian Fungi, version 2.00. [http://www.cybertruffle.org.uk/ukramaps/index.htm].

Mirek Z., Pięk os-Mirk owa H., Zając A., Zając M. 2002. Flowering plants and Pteridophytes of Poland. A checklist. Biodiversity of Poland 1: 1-442.

Müller J. 1977. Über die Verbreitung der Puccinia scillae Linhart. Ceska Mycologie 31 (3): 173-178

Mułenko W., Matejko Gosztyła E. 1997. Peronospora anhurï - a new species for Poland. Acta Mycol. 32 (1): 119-121.

Mułenko W., Piatek M., Wolezańska A., Kozłowska M. 2005. Grzyby inwazyjne. Pascżyty roślin przybyle do Polski w czasach nowcžytnych. (In:) Z Mi rek. (ed.) Rośliny inwazyjne Polski. W. Szafer Institute of Botany PAS. Inst. Bot. PAN, Kraków (in press).

Panditou M.E. 1973. Fungus-Host Index for Greece. Benaki Phytopathol. Inst., Kiphissia, Athens.

Pfosser M., S peta F. 1999. Phylogenetics of Hyacinthaceae based on plastid DNA sequences. Ann. of Missouri Bot. Garden 86 (4): 852-875.

Piątek M. 2000. Erysiphe echinopis, Microsphaera nussellii and Sphaerotheca spiraeac (Fungi, Erysiphales) - interesting powdery mildews on new sites in Poland. Fragm. Flor. Geobot. Polonica 7: 265-270.

Pią tek M. 2002: Erysiphe flexuosa, a new for Poland powdery mildew causing disease of Aesculus hippocastanum. Phytopathol. Pol. 24: 67-71.

Pią tek M. 2003. Erysiphe azaleae and Erysiphe syringac-japonicae introduced in Poland. Mycotaxon 87: 121-126. 
Piątek M. 2004. Miscellaneous novelties on powdery mildew fungi from Poland. Polish Bot. J. 49 (2): 151-159.

Piątek M., Ronikier M., Miśkiewicz A. 2001. New records and new host for Melampsoridium hiratsukantum (Fungi, Uredinales) in Poland. Fragm. Flor. Geobot. Polonica 8: 245-249.

Piękos-Mirkowa H., Mirek Z, 2003, Flora Polski. Atlas roslin chronionych. Multico, Warczawa.

Pôldma a K. 1997. Explosion of Melampsoridium sp. on Alnus incana. Folia Cryptog. Estonica 31: 48-50.

Poldma a K. 1999. Puccinia scillac Linh. New Estonian records: fungi. Folia Cryptog. Estonica 34: $88-89$.

Reid D.A. 1985. An annotated list of some fungi from the Channel Islands, mostly frum Jersey. Trans. Br. mycol. 84 (4): 709-714.

Rouppert K. W tóblewski A. 1910. Zapiski grzyboznawcze z Zalcseczyk. Kosmos 35: 260-265.

Ruszkiewicz M. 2000. Microscopic phytopathogenic fungi rare and new for Poland. Acta Mycol. 35 (1): $85-98$.

Ruszkiewicz-Michalska M., Mutenko W. 2003. Padis serotina (Rosaceae) - a new host plant for some species of parasitic microfungi. Acta Mycol. 38 (1/2): 51-58.

Rutkowski L 2004. Klucz do oznaczania roślin naczyniowych Polski niżowej. Wyd. Nauk. PWN, Warszawa.

Săvulescu Tr. 1953. Monographiae Uredinalium. II. Republicae Popularis Romanicae. Ed. Acad. Rep. Pop. Ron., Bucharest.

Scheuer Ch. 1998. Mycotheca Graccensis, Fasc. 8-10 (No. 141-200). Fritschiana 15: 1-21.

$\mathrm{S}$ chever Ch. 2000. Alphabetical index and Schedac emendatae to the exsiceata series Plantae Graecenses (hitp://www-ang.kfunigraz,ac.at/ scheuer/plagraec.html). Graz, Austria, Institut fur Botanik der Karl-Franzens-Universität.

Scheuer Ch. Poelt J. 1997. Mycotheca Graecensis, Fasc. 3-7 (No. 41-140). Fritschiana 9: 1-37.

Spet a F. 1958. Systematische Analyse der Gattung Scilla L. 8. L. (Hyacinthaceac). Phyton (Horn, Austria) 38: 1-141.

Syd ow P., Sy dow H. 1904. Monographia Uredinearim. Vol. I, Genus Puccinia. Fratres Borntraeger., Lipsiae.

The checklist of fungi of the British Isles. 2005. British Mycological Society. http./t 194.203.77.76/fieldmycology/GBCHECKLIST/.

Tranzs chel W. 1939. Conspectus uredinalium SSSR. Inst. Bot. Acad. Sci. SSSR, Moscow-Leningrad.

Triebel D. 1995-2004 [first posted on 95-12-01; most recent update: 03-10-27]). Microfungi exsiccati. - Online-version. Botanische Staatssammlung München: http://www botanischestaatssammlung.de/ arnoldia'microfu2.html - München.

Trotter A. 1908. Fora Italica Cryptogama. Pars I. Fungi. Fasc. N. 4. Uredinales. Genera: Uromyces et Puccina (in Compositis). Soc. Bot. Italiana.

Tutin T.G., Heywood V.H., Burges N.A. et al. eds. 1996. Flora Europaea. Vol. 5. Alismataceate to Orchidaceac (Monocotyledones). Cambridge Univ. Press, Cambridge, New York, Mclbourne.

Vấnky K. 1994. European smut fungi, G. Fischer Verlag, Stuttgart-Jena-New York.

Wetschnig W., P fosser M. 2003. The Scilla plumbea puzzle - present status of the genus Scilla sensu lato in southern Africa and description of Spetaea lachendilifora, a new genus and species of May. sonieae (Hyacinthaceae). Taxon 52 (1): $75-91$.

Wołczań ska A. 1999. Melampseridium hiratsukanum (Uredinales), a new species for Poland. Acta Mycol. $34(2): 345-347$.

Wołczańska A., Mułenko W. 2002. New collections of powdery mildews (Erysiphales) in Poland. Pol. Bot. J. 47 (2) $: 215-222$.

Wołczańska A., Oklejewicz K. 2001. New and rare species of parasitic fungi in Poland Acta Mycol. $36(1): 7-12$.

Wr 6 blewski A. 1916. Einige neue parasitische Pilzarten aus Polen. Bull. intemat. Acad. Sci. Cracovie, math.-nat., ser. B, 8-10:243-247, pl. 8.

Wr 6 blewski A. 1922. Grzyby zbion Jozefa Krupy z okolic Lwowa, Buczacza, Skolego i Tatt. Kosmos 47: 39-51.

Wróblewski A., Siemaszko W. 1933. Fungi polonici selecti exiccati. Decades $1-2$. Schedae ad herbarium Digessit W. Siemaszko, Varsovia. 
Zając A., Zają c M. eds. 2001. Distribution Atlas of Vascular Plants in Poland. Laboratory of Compu. ter Chorology, Inst. of Botany, Jagiellonian Univ., Cracow.

Zimmermannová-Pastirčaková K, Adamska I, Błaszkowski J., Bolay A, Braun U. 2002. Epidemic spread of Eyxiphe flexuora (North American powdery mildew of horse-chestnut) in Europe. Schlechtendalia 8: $39-45$.

Zweigb a u mów na Z. 1918. Grzybki pasorzytnicze na roslinach kwiatowych zcbrane w latach 1904-1911 w Smile gub. Kijowskiej i okolicach przez J. Trzebińskiego (Przyczynck do znajomości flory mykologicznej Ukrainy). Pam. Fizyogr. 25 (TV): 1-13.

\section{Puccinia scillae (Uredinales), gatunek nowy dla Polski}

\section{Streszezenic}

W pracy przedstawiono charakterystykẹ morfologiczną oraz analize rozmieszczenia w Europie nowego dla Polski gatunku grzyba rdzawnikowego porazającego uprawianą w celach dekoracyjnych cebulicę Scilla siberica. Dane z krajów osciennych wskazuja, ze gatunek ten mógł być dotąd w Polsce niezauważony, co może wynikać ze stabego stopnia zbadania siedlisk o charakterze antropogenicznym. Niewykluczone, że Puccinia scillae rozprzestrzenia się obecnie w północno-wschodniej Europie, co potwierdzałyby jego ostatnie notowania z Estonii. 